\title{
Adult T cell leukemia: A typical case from India
}

D ear Sir,

Adult T-cell leukemia/lymphoma (ATL) is a neoplastic disease of CD4-positive T Iymphocytes. H uman T-cell leukemia virus type I (HTLV-I) is critical for the development of ATL. [1] HTLV-I is endemic in $J$ apan. ${ }^{[2]}$ ATL has hardly been reported from India. ATL develops in only $2 \%$ to $4 \%$ of patients who are carriers of the HTLV-1 virus. ${ }^{[3]}$ We describe a case of 22 -year-old female who presented in July 2007 with two weeks history of swellings in neck, axilla, groin and extremities with generalized erythematous skin rash and bilateral decrease in hearing. She had pallor, edema feet, oral thrush, generalized lymphadenopathy with hepatospleenomegaly. The complete blood count showed hemoglobin of $8.59 \mathrm{gm} / \mathrm{dl}$ a WBC count of $306 \times 109 / \mathrm{L}$ with normal platelets. The peripheral smear showed atypical cleaved lymphocytes 50\% (Flower Cells), polymorph $16 \%$ and lymphocytes $34 \%$. She had mild azotemia with normal serum calcium but raised serum alkaline phosphatase 591.0 $\mathrm{U} / \mathrm{L}$ and raised serum LDH $524 \mathrm{U} / \mathrm{L}$. Peripheral blood immunophenotype show negative markers for myeloid, precursor cell, CD 10, CD 19, CD 3, CD 5, CD 7, cyto CD 3, TCR, NK cells and strongly positive for $C D 2, C D 4$ and $C D 25 .{ }^{[4]}$ Bone marrow aspirate and biopsy showed involvement by high grade $\mathrm{T}$ cell NHL. Serology for HTLV-1 was positive. Although she was normocalcemic the bone scan showed "super scan appearance". She did not respond to intensive ALL type BFM-90 protocol. She developed extensive pulmonary fungal infection and was subsequently lost to followup due to source constraints and expired at home five months after presentation. This case emphasizes that ATL can be seen in a non endemic area like India and has an aggressive course.

Jain P, Gupta S, Prabhash K, Patkar N, Parikh PM

Department of Medical Oncology and Hematopathology Laboratory, Tata Memorial Hospital, Dr. E. Borges Road, Parel, Mumbai-400 012, India. 
Correspondence to: Dr. Purvish M Parikh, E-mail: purvish@rediffmail.com

\section{References}

1. Poiesz BJ, Ruscetti FW, Gazdar AF, Bunn PA, Minna JD, Gallo RC. Detection and isolation of type $C$ retrovirus particles from fresh and cultured lymphocytes of a patient with cutaneous T-cell lymphoma. Proc Natl Acad Sci USA 1980;77:7415-9.

2. Takatsuki K, Matsuoka M, Yamaguchi K. Adult T-cell leukemia in Japan. J Acquir Immune Defic Syndr Hum Retrovirol 1996; 13:S 15-9.

3. Taylor GP. The epidemiology of HTLV-I in Europe. J Acquir Immune Defic Syndr Hum Retrovirol 1996;13:S8-14.

4. Matsuoka M. Human T-cell leukemia virus type I and adult T-cell leukemia. Oncogene 2003;22:5131-40. 